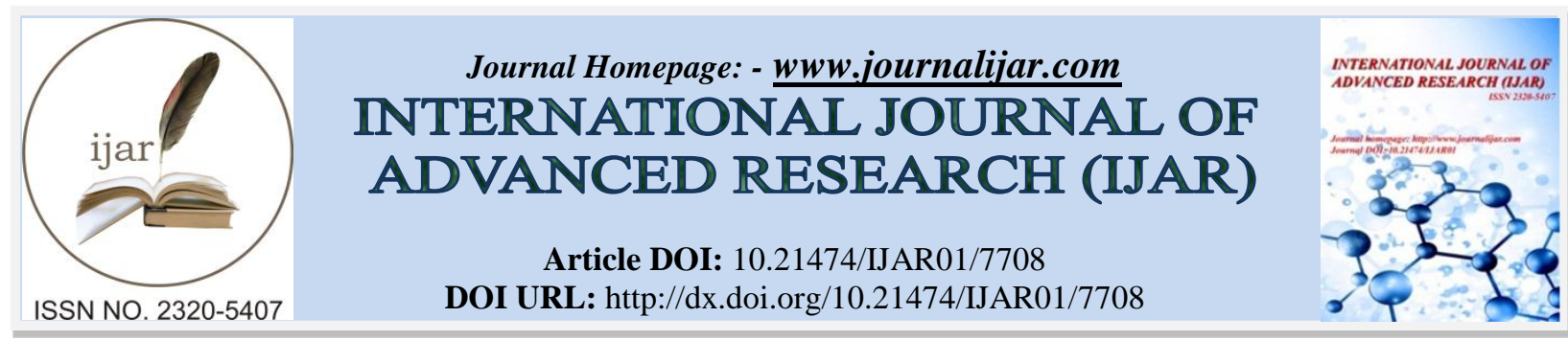

RESEARCH ARTICLE

\title{
ENHANCING THE EXISTING COFFEE GENETIC RESOURCES IN NIGERIA THROUGH IN VITRO CULTURE CONSERVATION.
}

\author{
Anagbogu CF, Muyiwa AA, Dada KE., Mapayi FE, Balogun ST, Iyoha SO and Adepoju AF. \\ Biotechnology Unit/ Crop Improvement division, Cocoa Research Institute of Nigeria (CRIN), Nigeria PMB 5244.
}

\section{Manuscript Info}

Manuscript History

Received: 20 July 2018

Final Accepted: 26 August 2018

Published: September 2018

Keywords:-

Biotechnology, Coffea spp.,

Conservation, Genetic resources, In vitro

culture, Somatic embryogenesis.

\begin{abstract}
This study aimed at enhancing and conserving existing coffee genetic resources in Nigeria through in vitro culture. In Nigeria there is an urgent need for proper maintenance of coffee genetic materials. This will pave way for sustainable improvement, safeguard against second collection of germplasm and loss of genetic resources. Establishment of easy, efficient and reliable in vitro library becomes paramount to complement field genebank which is the only form of conservation in Cocoa Research Institute of Nigeria. Callus tissues were generated from coffee leaf explant of C. canephora Pierre clone (C90). A DKW basal medium designed for culturing cocoa flower were used with three different hormonal combinations. Callus induction on the leaf was observed within 7days of culturing in the combination of Benzylamino Purine $(0.5 \mathrm{mg} / \mathrm{ml})$ and Indole Acetic Acid $(1 \mathrm{mg} / \mathrm{ml})$ and full callus development was reached at 14days. This callus was maintained in the second combination consisting of IAA $(2 \mathrm{mg} / \mathrm{L})+$ Thidiazuron $(25 \mathrm{ug} / \mathrm{L})$ for as long as 28days before changing to gray. The third combination, 2,4- Dichlorophenoxyacetic Acid $(2 \mathrm{mg} / \mathrm{L})+$ BAP $(1 \mathrm{mg} / \mathrm{L})+$ caseine hydrolysate $(200 \mathrm{mg} / \mathrm{L})+$ coconut water $(100 \mathrm{ml} / \mathrm{L})$ has the ability to convert gray callus to embryogenic or friable yellow callus which can be developed to plant prior converting to embryo in embryo development medium. This research has disclosed a proper and sustainable tissue culturing procedure of maintaining coffee germplasm and mass propagation of improved coffee variety for farmers.
\end{abstract}

Copy Right, IJAR, 2018,. All rights reserved.

\section{Introduction:-}

Coffee belongs to the plant family Rubiaceae. The two highly cultivated species are Coffea arabica and $C$. canephora. The latter has wide range of geographical distribution, from western to the central tropical and subtropical regions of the African continent (www.ico.org). It grows at low altitudes about $850 \mathrm{~m}$ and of high yielding and low quality. Genetic improvement of this crop with regard to quality poses a great challenge to researchers in Africa which lack a good and sustainable conservation technology for its genetic resources.

Collection and maintenance of germplasm are highly expensive and paramount so as to avoid genetic erosion or lost of genetic resources which are already narrow (Omolaja and Fawole, 2004). A great number of genetic resources should be properly conserved in any research institute to enhance and sustain its breeding and improvement programmes. For long traditional ex situ conservation method in the field genebank which offers a satisfactory 
approach to conservation has been the only conservation strategy. This provides an easy access to genetic resources (Engelmann et al., 2007). However, there are drawbacks that limit its efficiency and threaten its security. They are exposed to pests, diseases and other natural calamities (climate change and vandalism). Therefore there is a need for an alternative and sustainable conservation strategy.

Biotechnology offers alternative strategies for generating new and improved coffee varieties, including those resistances to environmental extremes, pests, and diseases, low in caffeine, and with uniform fruit maturation and in vitro conservation. In vitro technique has a wide range of applications, in mass propagation, conservation and genetic improvement. Large improvement in bioreactor scale-up of micropropagation through somatic embryogenesis has been achieved (Ducos et al., 2007).

Steps of somatic embryogenesis are induction of embryogenic calli, multiplication of the cells, regeneration of large numbers of embryos from these cells, finally conversion of these embryos into mature embryos regenerating to plantlets (Ducos et al., 2007). Propagation of coffee through cuttings generates low multiplication rates as only the orthotropic shoot is used (Kumar et al., 2006). This research aimed at preserving callus generated from coffee leaf of Coffea canephora var. Pierre (C90).

\section{Materials and Methods:- Plant materials}

Leaf explants was collected from C90 a clone of Coffea canephora from coffee seed garden at Cocoa Research Institute of Nigeria in Ibadan and subjected to in vitro .manipulation.

\section{Methods:-}

Young and fresh leaf from C90 was harvested using sterile blade and a clean $100 \mathrm{ml}$ beaker filled with distilled water and transported to the culturing room for surface sterilization. Few drops of detergent was drop in the beaker containing the leaf and washed under sterile condition in a flow hood. Surface sterilization was carried out by added $70 \%$ of ethanol for 1 minute and $10 \%$ of household bleach (Sodium Hypochlorite) for 15 minutes by gently shaking every $5 \mathrm{mins}$ to ensure uniform sterilization. The explant was re-rinsed three times with sterile distilled water. Sterilized leaf explant was placed on a sterile petri dish and cut into smaller disc with sterile forceps and blade and placed on PCG medium which consisted of DKW micro supplemented with BAP $(0.5 \mathrm{mg} / \mathrm{ml}) \mathrm{and}$ IAA $(1 \mathrm{mg} / \mathrm{ml})$, medium was sealed with parafilm and kept in the dark at $30^{\circ} \mathrm{C}$. After 7 days the calli formed was transferred to another media CMA and CMB (Table 1) after 2 weeks and subsequent calli transferred to SCD A and SCD B media (Table 1).

Table I:-Hormonal combination

\begin{tabular}{|c|c|c|c|c|c|c|}
\hline $\begin{array}{c}\text { Plant hormones and } \\
\text { other additives }\end{array}$ & \multicolumn{2}{|c|}{$\begin{array}{c}\text { Primary Callus } \\
\text { Development (PCD) }\end{array}$} & \multicolumn{2}{c|}{ Callus Maintenance (CM) } & \multicolumn{2}{c|}{$\begin{array}{c}\text { Secondary Callus } \\
\text { Development (SCD) }\end{array}$} \\
\hline & A & B & A & B & A & B \\
\hline BAP & $1 \mathrm{mg} / \mathrm{ml}$ & & $0.5 \mathrm{mg} / \mathrm{ml}$ & & $1 \mathrm{mg} / \mathrm{ml}$ \\
\hline IAA & $1 \mathrm{mg} / \mathrm{ml}$ & & & $0.2 \mathrm{mg} / \mathrm{ml}$ & $25 \mathrm{ug} / \mathrm{ml}$ & \\
\hline TDZ & & $0.2 \mathrm{mg} / \mathrm{ml}$ & & & $2 \mathrm{mg} / \mathrm{ml}$ \\
\hline 2,4-D & & $1 \mathrm{mg} / \mathrm{ml}$ & $1 \mathrm{mg} / \mathrm{ml}$ & & $200 \mathrm{mg} / \mathrm{ml}$ & $200 \mathrm{mg} / \mathrm{ml}$ \\
\hline Caseine hydrolysate & & & & & & $100 \mathrm{ml} / \mathrm{L}$ \\
\hline Coconut water & & & & & & \\
\hline
\end{tabular}




\section{Results:-}

Friable callus (Fig.1C) which can be converted to plantlets prior embryo was generated on DKW medium containing 2,4-D, BAP, casein hydrolysate and coconut water (SCDB). However, SCDA medium lacking coconut water formed no friable callus.

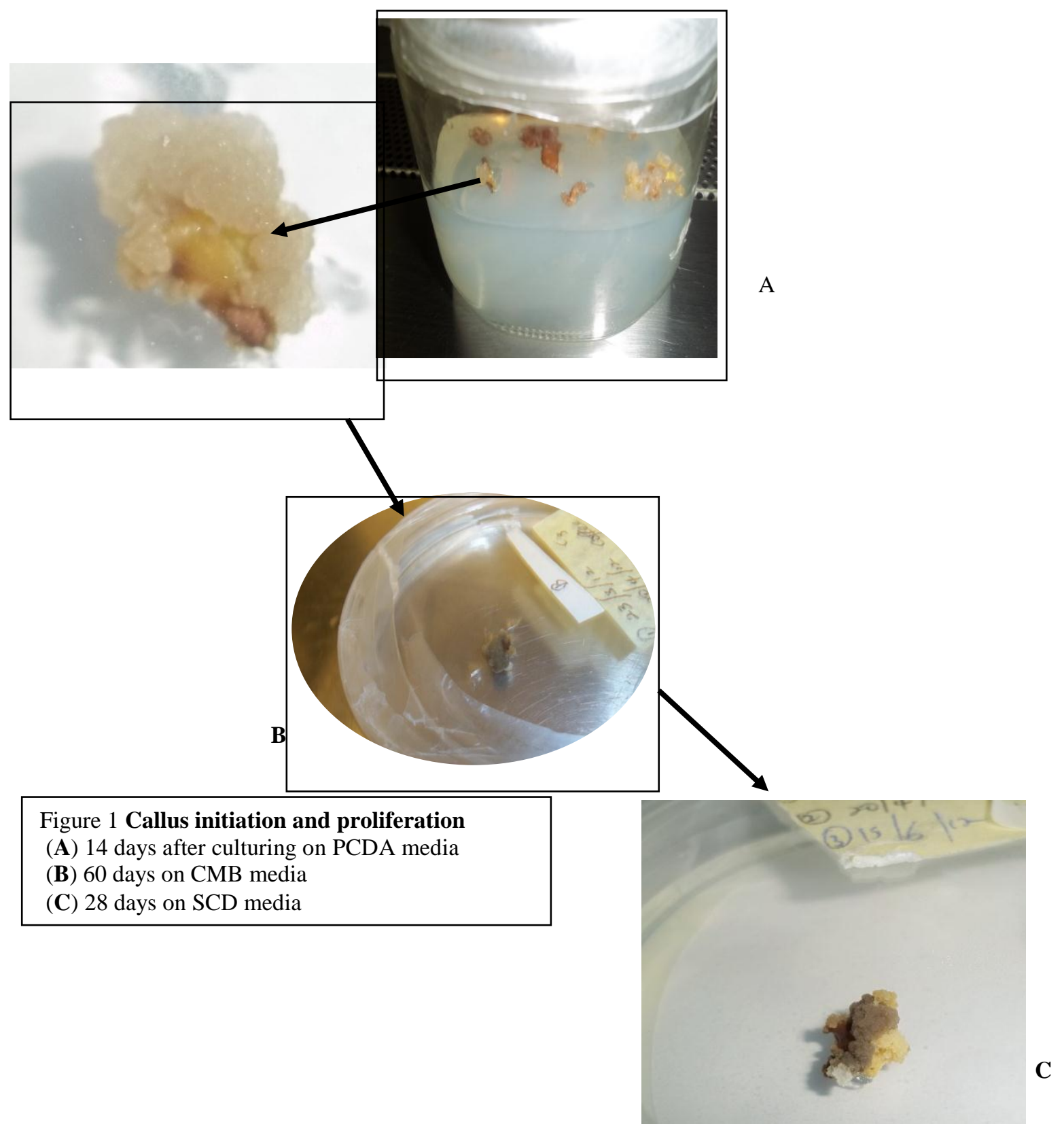

Also, CMA callus when transferred on SCDA medium reverted to white callus but no obvious change was observed when transferred on SCDB. However, when CMB callus was transferred to SCDA and SCDB they changed to yellow or friable callus but SCDB was more pronounced than the former. At initial culturing on both PCD A and PCD B, the former yielded callus at 1 week after culturing. It can therefore be deduced that SCDB is best to serve as SCD than SCDA for coffee leaf. 


\section{Discussion:-}

Callus production from coffee leaf offers a high potential in the future production of elite coffee variety (Ducos $e t$ al., 2007). In vitro conservation of coffee germplasm can be performed under two stages of development in vitro, either callus or plantlet stage. This has been demonstrated by this study where medium supplemented with IAA and TDZ (Table 1) was used in maintaining callus for 28 day.

The combination of BAP $(2 \mathrm{mg} / \mathrm{L})$ and NAA $(0.3 \mathrm{mg} / \mathrm{L})$ had yielded an increase in callus proliferation on Taxus baccata, the similar result was achieved in this experiment with BAP $(0.5 \mathrm{mg} / \mathrm{ml})$ and IAA $(1 \mathrm{mg} / \mathrm{ml})$. A DKW medium containing B5 Vitamin and supplemented BAP, 2,4-D and coconut water has the ability of converting gray callus to friable callus (Crocomo et al., 1986). The callus developed will be further transferred to a different medium to generate plantlets.

\section{Conclusion:-}

Maintaining or conserving genetic resources of coffee in the laboratory through the use of callus will serve as an alternative and cost effective way to compliment traditional field conservation so as to avoid the loss of genetic resources resulting from natural catastrophes.

\section{Acknowledgement:-}

We wish to thank the management of Cocoa Research Institute of Nigeria for providing facility for this work.

\section{References:-}

1. Abbasin, Z., Zamani, S., Movahedi, S., Khaksar, G., Sayed, B.E.S. (2010): In vitro Micropropagation of Yew (Taxus baccata) and Production of Plantlets. Biotechnology 9(1): 48-54.

2. Crocomo, O.J., Sharp, W.R., Evans, D.A., Bravo, J.E., Tavares, F.C.A., Paddock, E.F. (1986): Biotechnology of Plants and Microorganisms. Ohio State University Press, Columbus.

3. Ducos, J.P., Lambot, C., Petiard, V. (2007): Bioreactors for Coffee Mass Propagation by Somatic Embryogenesis. International Journal of Plant Developmental Biology 1(1): 1-12.

4. Engelmann, F., Dulloo, M.E., Astorga, C., Dussert, S., Anthony, F. (2007): Conserving coffee genetic resources. Tropical Reviews in Agricultural Biodiversity.

5. Omolaja, S.S., Fawole, I. (2004): Characterization of Nigerian robusta coffee (Coffea Canephora Pierra ex. Froehner) germplasm. In: Proceedings of $20^{\text {th }}$ International Conference on coffee science, Bangalore, India. 1115 October, 2004.

6. Kumar, V., Naidu, M.M., Ravishankar, G.A. (2006): Developments in coffee biotechnology-in vitro plant propagation and crop improvement. Plant Cell Tissue Organ Culture 87: 49-65.

7. Pennysylvania State University. Integrated system for vegetative propagation of cacao. Protocol Book. Version 2.1. November 17, 2010. 